Review

\title{
Recent Applications of Chitin- and Chitosan-Based Polymers in Plants
}

\author{
Massimo Malerba ${ }^{1}$ and Raffaella Cerana ${ }^{2, *}$ (D) \\ 1 Dipartimento di Biotecnologie e Bioscienze, Università degli Studi di Milano-Bicocca, 20126 Milan, Italy; \\ massimo.malerba@unimib.it \\ 2 Dipartimento di Scienze dell'Ambiente e della Terra, Università degli Studi di Milano-Bicocca, \\ 20126 Milan, Italy \\ * Correspondence: raffaella.cerana@unimib.it; Tel.: +39-0264482932
}

Received: 8 April 2019; Accepted: 7 May 2019; Published: 8 May 2019

\begin{abstract}
In recent years, the use of complex molecules based on the natural biopolymer chitin and/or on its deacetylated derivative chitosan has resulted in great advantages for many users. In particular, industries involved in the production of drugs, cosmetics, biotechnological items, and food have achieved better results using these particular molecules. In plants, chitin- and chitosan-based molecules are largely used as safe and environmental-friendly tools to ameliorate crop productivity and conservation of agronomic commodities. This review summarizes the results of the last two years on the application of chitin- and chitosan-based molecules on plant productivity. The open questions and future perspectives to overcome the present gaps and limitations are also discussed.
\end{abstract}

Keywords: chitin; chitosan; defense responses; nanoparticles; plant growth; pesticides

\section{Introduction}

Over the past decades, the use of products alternative to pesticides and chemical fertilizers in the control of pre- and post-harvest diseases and in the perspective to increase crop productivity has become more and more important in agriculture. Among the large variety of alternative products proposed so far, shrimp and crab exoskeleton powder chitin $(\mathrm{CH})$ and its deacetylated derivative chitosan (CHT) have been utilized by farmers as biopesticides, biofertilizers and as agricultural film in seeds and fruits coating since the 1980s [1]. Various methods of application of $\mathrm{CH}$ and $\mathrm{CHT}$ have been proposed (e.g., soil amendment, foliar, seed, and fruit application; $\mathrm{CH}$ or $\mathrm{CHT}$ alone or in combination with other treatments) to prevent the development of plant diseases or trigger plant innate defenses against pathogens [1]. The obtained results may vary and depend on various parameters including the pathosystem, the applied molecule, its concentration, the degree of deacetylation, viscosity, and the used formulation. To overcome these matters, in recent years many scientists have proposed to test molecules in which $\mathrm{CH}$ and $\mathrm{CHT}$ have been linked to other chemicals. The utilization of these complex molecules instead of $\mathrm{CH}$ and $\mathrm{CHT}$ alone has resulted in great advantages for chemical, biotechnological, cosmetic, and food industries [2]. Recent advances in the use of CHT polymers in agriculture were presented in a previous review [2]. Here, we summarize the results obtained during the last two years on the effects of chitin- and chitosan-based molecules supplied by traditional agricultural practices (e.g., seed and foliar spraying, soil amendment) on plant productivity and protection against pathogens with particular focus on nanoparticles.

\section{Chitin-Based Polymers}

Due to its high nitrogen content and low $\mathrm{C} / \mathrm{N}$ ratio, $\mathrm{CH}$ can be directly used as a fertilizer to enhance crop growth. The addition of chitin to the soil also improves microbial communities in both 
the abundances and structures. Application of $\mathrm{CH}$ in biocontrol of plant pathogens has also been extensively explored. In plants, $\mathrm{CH}$ is recognized by specific receptors present on the cell plasma membrane, such as the pathogen-associated molecular pattern (PAMP) receptor. After this recognition, $\mathrm{CH}$ can activate PAMP-triggered immunity that is able to induce defense responses against potential fungal, bacterial, and viral pathogens [3]. However, because of its high crystallinity, commercially available bulk $\mathrm{CH}$ is not soluble in most common solvents. Despite its utilizable functions, this lack of solubility limits not only its use in basic research, but also its practical application in agriculture [3]. In the search to overcome this limitation, several strategies have been adopted (Table 1).

Table 1. Recent application of chitin-based polymers.

\begin{tabular}{|c|c|c|c|}
\hline Plant Species & Chitin Characteristics & Chitin Effect & Reference \\
\hline Solanum lycopersicum & $\begin{array}{l}\text { From Saccharomyces } \\
\text { cerevisiae cell wall }\end{array}$ & Resistance against Botrytis cinerea & {$[4]$} \\
\hline Arabidopsis thaliana & $\begin{array}{c}\text { CH oligomers } \\
\text { (mainly tetramers) }\end{array}$ & $\begin{array}{l}\text { Increased fresh weight, radicle length and } \\
\text { total carbon and nitrogen content }\end{array}$ & {$[5]$} \\
\hline $\begin{array}{l}\text { Arabidopsis thaliana, } \\
\text { Oryza sativa japonica }\end{array}$ & CH oligomers & $\begin{array}{c}\text { Resistance against Alternaria brassicicola and } \\
\text { Pseudomonas syringae }\end{array}$ & {$[6]$} \\
\hline $\begin{array}{c}\text { Brassica oleracea, } \\
\text { Fragaria } \mathrm{x} \text { ananassa }\end{array}$ & $\mathrm{CH}$ nanofibers & $\begin{array}{l}\text { Resistance against Alternaria brassicicola and } \\
\text { Colletotrichum fructicola }\end{array}$ & [7] \\
\hline Solanum lycopersicum & $\begin{array}{c}\text { Protein } / \mathrm{CaCO}_{3} / \mathrm{CH} \\
\text { nanofibers or protein } / \mathrm{CH} \\
\text { nanofibers }\end{array}$ & $\begin{array}{l}\text { Plant growth, resistance against } \\
\text { Fusarium oxysporum }\end{array}$ & {$[8]$} \\
\hline Triticun aestivum & Nanochitin whisker & Yield, grain protein, iron, and zinc contents & [9] \\
\hline Triticun aestioum & Nanochitin whisker & $\begin{array}{c}\text { Resistance against Fusarium } \\
\text { pseudograminearum and Fusarium } \\
\text { graminearum }\end{array}$ & {$[10]$} \\
\hline Nicotiana tabacum L. & Nanochitin whisker & $\begin{array}{l}\text { Increased seed germination and growth, } \\
\text { resistance against Fusarium spp. }\end{array}$ & [11] \\
\hline $\begin{array}{l}\text { In vitro test of } \\
\text { pathogens growth }\end{array}$ & Iron/CH nanoparticles & $\begin{array}{l}\text { Inhibition of Pseudomonas aeruginosa, } \\
\text { Escherichia coli, Salmonella typhi and } \\
\text { Fusarium oxysporum growth }\end{array}$ & {$[12]$} \\
\hline
\end{tabular}

For example, the use of $\mathrm{CH}$ obtained from alternative sources was tested. Nowadays, the major source of this compound is crustacean waste. Sun and coworkers [4] proposed to test $\mathrm{CH}$ obtainable from Saccharomyces cerevisiae cell wall. $\mathrm{CH}$ extracted from yeast and other fungi has several advantages: (i) it cannot cause allergies in humans and animals like $\mathrm{CH}$ from arthropods; (ii) it has physical and chemical properties such as biodegradability, biocompatibility and nontoxicity, that make its use in agriculture easier [4]. Postharvest treatment of tomato fruits with $\mathrm{CH}$ from a yeast cell wall effectively induced strong resistance against gray mold rot caused by Botrytis cinerea. The authors attributed the increased disease resistance of $\mathrm{CH}$-treated tomato fruit to the accumulation of reactive oxygen species, to callose deposition, and to the increase in activities of defense-related enzymes, including superoxide dismutase, catalase, peroxidase, and chitinase along with the increase in the expression of the corresponding genes [4]. Other strategies propose the use of $\mathrm{CH}$ with lower molecular weight and therefore more easily soluble. For example, a $\mathrm{CH}$ oligosaccharide, obtained by mechanical grinding, autoclaving, and sonication of shrimp shells $\mathrm{CH}$ induced in Arabidopsis thaliana, the expression of genes related to vegetative growth and carbon and nitrogen metabolism. Compared with untreated plants, plants treated with the $\mathrm{CH}$ oligosaccharide showed increased fresh weight $(10 \%)$, radicle length, and total carbon and nitrogen content [5]. Alternatively, grinder pretreatment and the subsequent use of a high-pressure water jet system can disintegrate $\mathrm{CH}$ from crustacean shells into nanofibers. $\mathrm{CH}$ nanofibers (CNF) can be more feasibly used since they behave as a water-soluble material. Thus, they were tested for their elicitor capacity, and Egusa et al. first showed that CNF enhanced resistance against pathogens in A. thaliana and rice [6]. More recently, when challenged with the fungal pathogens, cabbage and strawberry plants, grown in a mixture of soil and CNF, showed a reduction in the number 
of spots caused by Alternaria brassicicola and lesion size by Colletotrichum fructicola in respect to control plants [7]. The addition of CNF to soil slightly enhanced tomato plants growth and reduced the incidence of Fusarium wilt disease relative to CNF-untreated plants. Disease inhibition was more effective utilizing $\mathrm{CNF}$ complexed with both protein and $\mathrm{CaCO}_{3}$ in protein/ $/ \mathrm{CaCO}_{3} /$ chitin nanofiber $(\mathrm{P} / \mathrm{Ca} / \mathrm{CNF})$ or only with protein in protein/chitin nanofiber $(\mathrm{P} / \mathrm{CNF})[8]$. Similarly, acidic hydrolysis of shrimp $\mathrm{CH}$ can lead to obtain rod-like particles with a cationic nature and high biological activities named nanochitin whisker (NCW). In outside pot experiments, two varieties of winter wheat treated with the NCW showed enhanced yield with significant increases of net photosynthesis, stomatal conductance, intercellular $\mathrm{CO}_{2}$ concentrations, and transpiration rate in flag leaf at the grain filling stage. Grain protein, iron, and zinc contents also increased in NCW-treated wheat [9]. In wheat, the antifungal activity of NCW was also tested. Liang et al. [10] showed that in a pot test NCW had significant inhibitory effects on mycelial growth and conidial production of Fusarium pseudograminearum and F. graminearum causing agents of crown rot, the most damaging disease in this crop. In indoor and field trials, NCW also stimulated tobacco seed germination and seedling growth (i.e., stem length and girth, leaf number and area). In addition, when mixed with metalaxyl mancozeb and thiophanate methyl fungicides, NCW had synergistic effects on inhibition of tobacco root rot, suggesting its potential utilization for reducing the use of chemical fungicides in tobacco plantations [11]. Finally, $\mathrm{CH}$ nanoparticles mechanically prepared from shells of Penaeus semisulcatus were fused to iron. In in vitro experiments using standard antibiotics as positive controls, the obtained nanocomposite showed antimicrobial activity against Pseudomonas aeruginosa, Escherichia coli, Salmonella typhi, and to a lesser extent against $F$. oxysporum, suggesting its utilization against various bacterial and fungal pathogens [12].

\section{Chitosan-Based Polymers}

Extensive use of chemicals in agriculture to increase plant productivity and resistance against pathogens can cause irreversible damage to the ecosystem due to their accumulation in the environment and in the living organisms. In addition, it can induce the appearance of resistance in plant pathogens and the subsequent necessity to introduce new agrochemicals and/or to increase the use dosage of existing products [13]. This obviously increases costs and risks. In the search for new approaches to solve this dilemma, application of nanotechnology appears very promising. Chitosan (CHT) is one of the most useful biomaterials in nanotechnology due to its biodegradability, biocompatibility, and nontoxicity to humans. In addition, CHT can easily be modified without affecting its innate capabilities as compared to other biopolymers like chitin, starch, gelatin, cellulose, and glucans [14]. Therefore, CHT has been widely used for various applications through modifications of its physicochemical and biophysical properties. Recently, in plants, a large spectrum of antimicrobial and regulatory activities were obtained by the use of CHT-based molecules. For example, CHT nanoparticles (CHTNP), having the properties of $\mathrm{CHT}$ and the characteristics of nanoparticles such as surface and interface effect, small size and quantum size effects, were able to act as germination elicitor of Oryza sativa L. [15] and to positively affect seed germination and seedling growth of wheat (Triticum aestivum L.) [16]. In addition, these nanoparticles were able to induce the expression of pathogenesis-related proteins thus enhancing resistance against $F$. andiyazi in tomato [17] and to inhibit $F$. oxysporum growth in Zingiber officinale [18]. CHTNP complexed with other molecules were largely used to promote plant growth and to induce resistance against phytopathogens. Entrapment of nitrogen, phosphorous, and potassium into CHTNP enhanced uptake of nutrients, photosynthesis, and growth of treated coffee plants [19] and induced starch and major proteins accumulation in Pisum sativum plants [20]. CHTNP complexed with different metals were tested for growth promotion and induction of resistance (Table 2). 
Table 2. Recent application of chitosan-based nanoparticles complexed with metals.

\begin{tabular}{|c|c|c|c|}
\hline Plant Species & $\begin{array}{l}\text { Metal Complexed to } \\
\text { CHT Nanoparticles }\end{array}$ & Effect & Reference \\
\hline $\begin{array}{l}\text { Triticum turgidum } \\
\text { var. durum }\end{array}$ & $\mathrm{Zn}$ & Gluten content increase & [21] \\
\hline Zea mays & $\mathrm{Zn}$ & Crop yield promotion & [22] \\
\hline Gossypium spp. & $\mathrm{Zn}$ or $\mathrm{Cu}$ & Resistance against Rhizoctonia solani & [23] \\
\hline Allium cepa L. & $\mathrm{Cu}$ & $\begin{array}{l}\text { Increase of plant growth and nutrient content } \\
\text { of bulbs }\end{array}$ & [24] \\
\hline Eleusine coracana & $\mathrm{Cu}$ & $\begin{array}{l}\text { Increase of plant growth and resistance against } \\
\text { Pyricola grisea }\end{array}$ & [25] \\
\hline Cicer arietinum $\mathrm{L}$. & $\mathrm{CuO}, \mathrm{ZnO}$ or $\mathrm{Ag}$ & Resistance against Fusarium oxysporum & [26] \\
\hline Hevea brasiliensis & $\mathrm{Ag}$ & Resistance against Corynespora cassiicola & [27] \\
\hline Piper nigrum & $\mathrm{Ag}$ & Resistance against Phytophthora capsici & [28] \\
\hline Oryza sativa $\mathrm{L}$. & $\mathrm{La}$ & $\begin{array}{l}\text { Growth promotion and improved } \\
\text { disease resistance }\end{array}$ & [29] \\
\hline
\end{tabular}

Foliar and seeds treatment with zinc-loaded CHTNP enhanced gluten content in durum wheat [21] and promoted crop yield in maize [22], while $\mathrm{Cu}$ - and $\mathrm{Zn}$-CHTNP suppressed cotton seedling disease caused by Rhizoctonia solani [23]. Cu-CHTNP increased yield, plant growth, and nutrient content of onion bulbs [24], and it stimulated growth and induced resistance in finger millet plants against blast disease caused by Pyricula grisea [25]. Different metal- CHTNP (CuO-, ZnO, and Ag-CHTNP) prevented Fusarium wilt, the seed borne and soil borne disease caused by F. oxysporum on chickpea [26]. Ag-CHTNP application controlled leaf fall disease caused by Corynespora cassiicola on rubber trees [27] and significantly affected Phytophthora capsici growth on pepper plants [28], while lanthanum-CHTNP effectively promoted growth and improved disease resistance of rice [29].

The use of CHTNP complexed with molecules such as elicitors, secondary metabolites, and phytoregulators was also tested (Table 3).

Treatment of tomato plants with harpin-CHTNP resulted in different expression of several genes involved in defense response and decreased R. solani infection [30]. At the appropriate concentration, tripolyphosphate-CHTNP stimulated micropropagation plant growth on Capsicum annuum while toxic doses dramatically caused cessation of plant growth [31]. Thiamine-CHTNP stimulated growth and induced resistance against F. oxysporum in chickpea seedlings [32], while salicylic acid-CHTNP positively modulated plant growth and improved defense responses on lettuce seedlings [33] and promoted growth and defense in maize [34]. Under laboratory conditions, CHTNP, encapsulated with Cymbopogon martinii essential oil, exhibited antifungal and antimycotoxin activities against F. graminearum in maize grains [35]. Coumarin-functionalized CHT derivatives affected A. solani, F. oxysporum, and F. moniliforme growth [36]. CHT, vanillin, and salicylic acid hybrids effectively induced resistance against Puccinia recondita and Cochliobolus sativus in wheat [37]. A bentonite-CHT nanoclay showed antimicrobial action against $P$. syringe and $F$. solani and exerted elicitor action on tomato plantlets [38]. CHTNP derivatives positively affect the responses to abiotic stresses, too. For example, $\mathrm{Cu}-\mathrm{CHTNP}$ enhanced growth and expression of defense genes in tomato plants under salt stress [39], and S-nitrosoglutathione-CHTNP improved drought tolerance of sugarcane plants [40]. 
Table 3. Recent application of CHT-based polymers and nanoparticles complexed with different molecules.

\begin{tabular}{|c|c|c|c|}
\hline Plant Species & $\begin{array}{l}\text { Molecule Complexed to } \\
\text { CHT }\end{array}$ & Effect & Reference \\
\hline Solanum lycopersicum & Harpin & Resistance against Rhizoctonia solani & [30] \\
\hline Capsicum annuum & Tripolyphosphate & $\begin{array}{l}\text { Stimulation of plant growth and biomass } \\
\text { accumulation }\end{array}$ & [31] \\
\hline Cicer arietinum $\mathrm{L}$. & Thiamine & $\begin{array}{l}\text { Stimulation of plant growth and resistance } \\
\text { against Fusarium oxysporum }\end{array}$ & [32] \\
\hline Lactuca sativa $\mathrm{L}$. & Salicylic acid & $\begin{array}{l}\text { Stimulation of plant growth and improved } \\
\text { disease resistance }\end{array}$ & [33] \\
\hline Zea mays L. & Salicylic acid & $\begin{array}{l}\text { Stimulation of plant growth and improved } \\
\text { disease resistance }\end{array}$ & [34] \\
\hline Zea mays L. & $\begin{array}{l}\text { Cymbopogon martinii } \\
\text { essential oil }\end{array}$ & Resistance against Fusarium graminearum & [35] \\
\hline Hevea brasiliensis & Coumarin & $\begin{array}{l}\text { Resistance against Alternaria solanii and } \\
\text { Fusarium spp. }\end{array}$ & [36] \\
\hline Triticum aestivum $\mathrm{L}$. & Vanillin and salicylic acid & $\begin{array}{l}\text { Resistance against Puccinia recondita and } \\
\text { Cochliobolus sativus }\end{array}$ & [37] \\
\hline Solanum lycopersicum & Bentonite & $\begin{array}{l}\text { Resistance against } P \text { seudomonas syringe and } \\
\text { Fusarium solani }\end{array}$ & [38] \\
\hline Solanum lycopersicum & $\mathrm{Cu}$ & $\begin{array}{l}\text { Stimulation of plant growth and expression } \\
\text { of defense genes }\end{array}$ & [39] \\
\hline Saccarum spp. & S-nitrosoglutathione & Improved drought tolerance & [40] \\
\hline
\end{tabular}

Finally, CHT-based polymers were also tested for the construction of film for fruits and seeds coating (Table 4).

Table 4. Recent application of chitosan-based polymers and nanoparticles for fruits and seeds coating.

\begin{tabular}{|c|c|c|c|}
\hline Plant Species & CHT-Based Polymer & Effect & Reference \\
\hline $\begin{array}{l}\text { Musa acuminata AAA } \\
\text { group }\end{array}$ & CHT nanoparticles & $\begin{array}{l}\text { Shelf life extension and maintenance of } \\
\text { fruit quality }\end{array}$ & [41] \\
\hline Vaccinium myrtillus & $\mathrm{CHT}+$ procyanidins & $\begin{array}{l}\text { Promotion of quality maintenance and } \\
\text { inhibition of fruit pathogens growth }\end{array}$ & [42] \\
\hline Citrus reticulata Blanco & $\begin{array}{l}\text { CHT + Ficus hirta Vahl. } \\
\text { fruits extract }\end{array}$ & $\begin{array}{l}\text { Reduction postharvest loss and } \\
\text { enhancement of fruits storability }\end{array}$ & [43] \\
\hline Fragaria $\times$ ananassa Duch. & $\begin{array}{l}\mathrm{CHT}+\text { photoactivated } \\
\text { chlorophyllin }\end{array}$ & $\begin{array}{l}\text { Extension of fruit shelf life and inhibition } \\
\text { of pathogens growth }\end{array}$ & [44] \\
\hline $\begin{array}{l}\text { Zizyphus jujuba Mill. cv } \\
\text { Dongzao }\end{array}$ & $\begin{array}{l}\text { CHT/nano-silica/sodium } \\
\text { alginate }\end{array}$ & $\begin{array}{l}\text { Extension of fruit shelf life and inhibition } \\
\text { of pathogens growth }\end{array}$ & [45] \\
\hline Ginkgo biloba L. & $\begin{array}{l}\mathrm{CHT} / \text { nano- } \mathrm{TiO}_{2} \text { and } \\
\mathrm{CHT} / \text { nano- }-\mathrm{SiO}_{2}\end{array}$ & Preservation of seeds quality & [46] \\
\hline
\end{tabular}

Application of CHTNP extended shelf life and maintained quality of banana fruits [41], while $\mathrm{CHT}+$ procyanidins coating promoted quality maintenance and inhibited microbial growth of fresh blueberry [42]. Coating with Ficus hirta Vahl. fruits extract-incorporated CHT reduced postharvest loss and enhanced the storability of Xinyu tangerines during cold storage by antimicrobial activity [43]. Coating with a photoactivated chlorophyllin-CHT conjugate diminished microbial contamination thus prolonging the shelf life of strawberries without any negative impact on commodities aspect and quality [44]. Treatment of winter jujube fruits with a CHT/nano-silica/sodium alginate composite film prolonged the fruit shelf life by increasing the expression of antioxidant genes [45]. In addition, $\mathrm{CHT} /$ nano- $\mathrm{TiO}_{2}$ and chitosan/nano-SiO${ }_{2}$ coating films preserved Ginco biloba seeds quality by positively affecting the activities of scavenger antioxidant enzymes [46]. 


\section{Open Questions, Future Perspectives, and Conclusions}

In plants, investigations of the molecular mechanism of $\mathrm{CH}$ perception and $\mathrm{CH}$-induced immunity led to the discovery of a specific receptor, which is a plasma membrane LysM- containing protein. After the recognition of $\mathrm{CH}$ by this receptor, a well-defined signaling cascade leads to the responses [47]. Different mechanism of action of CHT and its derivatives are reported in the literature. Metal-chelation and/or interaction between positively charged CHT and anionic molecules of cell/wall/DNA of microbes may lead to leakage of intracellular components or to inhibition of mRNA and protein synthesis. This can directly kill the pathogen. Similarly, CHT appears to elicit responses from plant cells via electrostatic interactions with negatively charged molecules instead of via interaction with a specific receptor like $\mathrm{CH}$ [3]. In fact, a strong electrostatic interaction exists between polycationic $\mathrm{CHT}$ and polyanionic structures like lipopolysaccharides, proteins, and metal ions present in the cell wall and in the cell plasma membrane. In addition, the negatively charged phosphate groups of DNA offer an excellent binding surface to cationic groups of $\mathrm{CHT}$. This binding can lead to specific modifications in protein expression [48]. Anyway, with a genetic approach some studies suggest the presence of putative CHT receptors [49] and, recently, the CHT perception by the $\mathrm{CH}$ receptor CERK1 has been clearly demonstrated [50].

Although there are many reports of the application of $\mathrm{CH}, \mathrm{CHT}$, and $\mathrm{CHT}$ derivatives in agriculture, much work remains to be done. Most of these studies are still at the laboratory or greenhouse level and field trials are needed. In particular, the effect of these molecules on ambient and soil biome must be evaluated. For example, several reports show that metals- and metal oxides-containing CHT nanoparticles are under advanced investigation for use in agriculture. The reports on the toxicity of these metal-containing CHT derivatives on plants and subsequently on soil, terrestrial ecosystems and humans are contradictory and initial risk studies seem to undervalue toxicity issues. However, recent investigations raised serious worries about the toxicity of residual metals. Thus, the issue of toxicity of these metal-containing compounds in living organisms and their fate in soil, water and air is a source of serious apprehension and several scientists suggest further research for concrete conclusions [2].

A nanotechnological approach in agriculture is very promising to increase the efficacy of agrochemicals and lower their environmental impact. Several evidences show that CHT nanoparticles could be a smart system for the controlled release of various agrochemicals including pesticides, micronutrients, fertilizers, and plant hormones, and they are able to play a dual role in plant growth regulation and protection against phytopathogens [2]. Several commercial products have been developed for application in agriculture, for example CHITOSAN 6 from RUMEXO Ltd (Derby, United Kingdom) and different types of CHT preparations from G.T.C. Bio Corporation (Guingdao, China). In spite of this, the reported applications are limited. The main obstacle that hinders wide utilization of these CHT derivatives in field is the immense and still not well-known bioactivity of these compounds against bacteria, fungi, viruses, and plants. Concomitantly, mechanisms of interaction of CHT derivatives towards microbes and plants are not well understood especially because the different biophysicochemical characteristics of different $\mathrm{CHT}$ preparations led to a discrepancy in degree of bioactivities/reproducibility of results [3]. Therefore, since CHT is indeed cumbersome and very expensive to customize into stable and desired nanoforms, the future task for scientists is to implement new large-scale production processes for preparation of the desired CHT-based molecules.

Finally, promising results have been very recently obtained in the plant genetic engineering field. Genetic engineering is an important tool for sustainable increase of crop productivity and biosynthesis of useful molecules. The use of CHT-based molecules seems to allow the overcoming of some concerns about conventional engineering methods like polyethylene glycol-mediated transformation or particle bombardment. In particular, chitosan-complexed single-walled carbon nanotube carriers appeared and are able to deliver plasmid DNA selectively to chloroplasts of different plant species, including tobacco, spinach, and the model plant $A$. thaliana without the risk to affect nuclear genome [51].

To conclude, despite the open challenges, molecules based on $\mathrm{CH}$ and $\mathrm{CHT}$ have proved useful in various aspects of plant biology, ranging from the increase in crop yield to the protection against the 
attack of pathogens. The huge number of papers recently published testifies to the interest of scientists for the use in agriculture of these molecules and this should lead to relevant progress in a short period and extension of their use to other parts of plant life.

Funding: This research was funded by University of Milano-Bicocca, Fondo d'Ateneo per la Ricerca.

Conflicts of Interest: The authors declare that they have no conflict of interest.

\section{References}

1. Malerba, M.; Cerana, R. Chitosan effects on plant systems. Int. J. Mol. Sci. 2017, 17, 996. [CrossRef]

2. Malerba, M.; Cerana, R. Recent advances of chitosan application in plants. Polymers 2018, 10, 118. [CrossRef] [PubMed]

3. Pusztahelyi, T. Chitin and chitin-related compounds in plant-fungal interactions. Mycology 2018, 9, $189-201$. [CrossRef]

4. Sun, C.; Fu, D.; Jin, L.; Chen, M.; Zheng, X.; Yu, T. Chitin isolated from yeast cell wall induces the resistance of tomato fruit to Botrytis cinerea. Carbohydr. Polym. 2018, 199, 341-352. [CrossRef] [PubMed]

5. Winkler, A.J.; Dominguez-Nuñez, J.A.; Aranaz, I.; Poza-Carrión, C.; Ramonell, K.; Somerville, S.; Berrocal-Lobo, M. Short-chain chitin oligomers: promoters of plant growth. Mar. Drugs 2017, 15, 40. [CrossRef]

6. Egusa, M.; Matsui, H.; Urakami, T.; Okuda, S.; Ifuku, S.; Nakagami, H.; Kaminaka, H. Chitin nanofibers elucidates the elicitor activity of polymeric chitin in plants. Front. Plant Sci. 2015, 6, 1098-1105. [CrossRef]

7. Parada, R.Y.; Egusa, M.; Aklog, Y.F.; Miura, C.; Ifuku, S.; Kaminaka, H. Optimization of nanofibrillation degree of chitin for induction of plant disease resistance: elicitor activity and systemic resistance induced by chitin nanofiber in cabbage and strawberry. Int. J. Biol. Macromol. 2018, 118, 2185-2192. [CrossRef] [PubMed]

8. Egusa, M.; Parada, R.Y.; Aklog, Y.F.; Ifuku, S.; Kaminaka, H. Nanofibrillation enhances the protective effect of crab shells against Fusarium wilt disease in tomato. Int. J. Biol. Macromol. 2019, 128, 22-27. [CrossRef] [PubMed]

9. Xue, W.; Han, Y.; Tan, J.; Wang, Y.; Wang, G.; Wang, H. Effects of nanochitin on the enhancement of the grain yield and quality of winter wheat. J. Agric. Food Chem. 2018, 66, 6637-6645. [CrossRef]

10. Liang, R.; Li, X.; Yuan, W.; Jin, S.; Hou, S.; Wang, M.; Wang, H. Antifungal activity of nanochitin whisker against crown rot diseases of wheat. J. Agric. Food Chem. 2018, 66, 9907-9913. [CrossRef]

11. Zhou, Y.; Jiang, S.; Jiao, Y.; Wang, H. Synergistic effects of nanochitin on inhibition of tobacco root rot disease. Int. J. Biol. Macromol. 2017, 99, 205-212. [CrossRef] [PubMed]

12. Gomaa, Z.E. Iron nanoparticles a-chitin nanocomposite for enhanced antimicrobial, dyes degradation and heavy metals removal activities. J. Polym. Environ. 2018, 26, 3638-3654. [CrossRef]

13. Kumaraswamy, R.V.; Kumari, S.; Choudhary, R.C.; Pal, A.; Raliya, R.; Biswas, P.; Saharan, V. Engineered chitosan based nanomaterials: bioactivities, mechanisms and perspectives in plant protection and growth. Int. J. Biol. Macromol. 2018, 113, 494-506. [CrossRef] [PubMed]

14. Divya, K.; Jisha, M.S. Chitosan nanoparticles preparation and applications. Environ. Chem. Lett. 2018, 16, 101-112. [CrossRef]

15. Divya, K.; Jisha, M.S.; Vijayan, S.; Nair, S.J. Optimization of chitosan nanoparticle synthesis and its potential application as germination elicitor of Oryza sativa L. Int. J. Biol. Macromol. 2019, 124, 1053-1059. [CrossRef]

16. Li, R.; He, J.; Xie, H.; Wang, W.; Bose, S.K.; Sun, Y.; Hu, J.; Yin, H. Effects of chitosan nanoparticles on seed germination and seedling growth of wheat (Triticum aestivum L.). Int. J. Biol. Macromol. 2019, 126, 91-100. [CrossRef]

17. Chun, S.-C.; Chandrasekaran, M. Chitosan and chitosan nanoparticles induced expression of pathogenesis-related proteins genes enhances biotic stress tolerance in tomato. Int. J. Biol. Macromol. 2019, 125, 948-954. [CrossRef]

18. Athawale, V.; Paralikar, P.; Avinash, P.; Ingle, A.P.; Rai, M. Biogenically engineered nanoparticles inhibit Fusarium oxysporum causing soft-rot of ginger. IET Nanobiotechnol. 2018, 12, 1084-1089. [CrossRef]

19. Ha, N.M.C.; Nguyen, T.H.; Wang, S.-L.; Nguyen, A.D. Preparation of NPK nanofertilizer based on chitosan nanoparticles and its effect on biophysical characteristics and growth of coffee in green house. Res. Chem. Intermed. 2019, 45, 51-63. [CrossRef] 
20. Khalifa, N.S.; Hasanen, M.N. The effect of chitosan-PMAA-NPK nanofertilizer on Pisum sativum plants. 3 Biotech 2018, 8, 193. [CrossRef]

21. Deshpande, P.; Dapkekar, A.; Oak, M.; Paknikar, K.; Rajwade, J. Nanocarrier-mediated foliar zinc fertilization influences expression of metal homeostasis related genes in flag leaves and enhances gluten content in durum wheat. PLoS ONE 2018, 13, e0191035. [CrossRef]

22. Choudhary, R.C.; Kumaraswamy, R.V.; Kumari, S.; Sharma, S.S.; Pal, A.; Raliya, R.; Biswas, P.; Saharan, V. Zinc encapsulated chitosan nanoparticle to promote maize crop yield. Int. J. Biol. Macromol. 2019, 127, 126-135. [CrossRef]

23. Abd-Elsalam, K.A.; Vasil'kov, A.Y.; Said-Galiev, E.E.; Rubina, M.S.; Khokhlov, A.R.; Naumkin, A.R.; Shtykova, E.V.; Alghuthaymi, M.A. Bimetallic blends and chitosan nanocomposites: novel antifungal agents against cotton seedling damping-off. Eur. J. Plant Pathol. 2018, 151, 57-72. [CrossRef]

24. Abd El-Aziz, M.E.; Morsi, S.M.M.; Salama, D.M.; Abdel-Aziz, M.S.; Mohamed, S.; Abd Elwahed, M.S.; Shaaban, E.A.; Youssef, A.M. Preparation and characterization of chitosan/polyacrylic acid/copper nanocomposites and their impact on onion production. Int. J. Biol. Macromol. 2019, 123, 856-865. [CrossRef] [PubMed]

25. Sathiyabama, M.; Manikandan, A. Application of copper-chitosan nanoparticles stimulate growth and induce resistance in finger millet (Eleusine coracana Gaertn.) plants against blast disease. J. Agric. Food Chem. 2018, 66, 1784-1790. [CrossRef]

26. Kaur, P.; Duhan, J.S.; Thakur, R. Comparative pot studies of chitosan and chitosan-metal nanocomposites as nano-agrochemicals against fusarium wilt of chickpea (Cicer arietinum L.). Biocatal. Agric. Biotechnol. 2018, 14, 466-471. [CrossRef]

27. Nhien, L.T.A.; Luong, N.D.; Tien, L.T.T.; Luan, L.Q. Radiation synthesis of silver nanoparticles/chitosan for controlling leaf fall disease on rubber trees causing by Corynespora cassiicola. J. Nanomater. 2018. [CrossRef]

28. Luan, L.Q.; Xo, D.H. In vitro and in vivo fungicidal effects of $\gamma$-irradiation synthesized silver nanoparticles against Phytophthora capsici causing the foot rot disease on pepper plant. J. Plant Pathol. 2018, 100, 241-248. [CrossRef]

29. Liang, W.; Yu, A.; Wang, G.; Zheng, F.; Hu, P.; Jia, J.; Xu, H. A novel water-based chitosan-La pesticide nanocarrier enhancing defense responses in rice (Oryza sativa L) growth. Carbohydr. Polym. 2018, 199, 437-444. [CrossRef]

30. Nadendla, S.R.; Rani, T.S.; Vaikuntapu, P.R.; Maddu, R.R.; Podile, A.R. Harpin ${ }_{\text {Ps }}$ encapsulation in chitosan nanoparticles for improved bioavailability and disease resistance in tomato. Carbohydr. Polym. 2018, 199, 11-19. [CrossRef]

31. Asgari-Targhi, G.; Iranbakhsh, A.; Ardebili, Z.O. Potential benefits and phytotoxicity of bulk and nano-chitosan on the growth, morphogenesis, physiology, and micropropagation of Capsicum annuum. Plant Physiol. Biochem. 2018, 127, 393-402. [CrossRef] [PubMed]

32. Sathiyabama, M.; Indhumathi, M.; Muthukumar, S. Chitosan nanoparticles loaded with thiamine stimulate growth and enhances protection against wilt disease in Chickpea. Carbohydr. Polym. 2019, 212, 169-177.

33. Martin-Saldaña, S.; Chevalier, M.T.; Iglesias, M.J.; Colman, S.L.; Casalongué, C.A.; Álvarez, V.A.; Chevalier, A.A. Salicylic acid loaded chitosan microparticles applied to lettuce seedlings: recycling shrimp fishing industry waste. Carbohydr. Polym. 2018, 200, 321-331. [CrossRef] [PubMed]

34. Kumaraswamy, R.V.; Kumari, S.; Choudhary, R.C.; Sharma, S.S.; Pal, A.; Raliya, R.; Biswas, P.; Saharan, V. Salicylic acid functionalized chitosan nanoparticle: a sustainable biostimulant for plant. Int. J. Biol. Macromol. 2019, 123, 59-69. [CrossRef] [PubMed]

35. Kalagatur, N.K.; Ghosh, O.S.N.; Sundararaj, N.; Mudili, V. Antifungal activity of chitosan nanoparticles encapsulated with Cymbopogon martinii essential oil on plant pathogenic fungi Fusarium graminearum. Front. Pharmacol. 2018, 9. [CrossRef] [PubMed]

36. Yang, G.; Jin, O.; Xu, C.; Fan, S.; Wang, C.; Xie, P. Synthesis, characterization and antifungal activity of coumarin-functionalized chitosan derivatives. Int. J. Biol. Macromol. 2018, 106, 179-184. [CrossRef]

37. Popova, E.V.; Domnina, N.S.; Kovalenko, N.M.; Sokornova, S.V.; Tyuterev, S.L. Influence of chitosan hybrid derivatives on induced wheat resistance to pathogens with different nutrition strategies. Appl. Biochem. Microbiol. 2018, 54, 535-539. [CrossRef]

38. Merino, D.; Mansilla, A.Y.; Casalongué, C.A.; Alvarez, V.A. Preparation, characterization, and in vitro testing of nanoclay antimicrobial activities and elicitor capacity. J. Agric. Food Chem. 2018, 66, 3101-3109. [CrossRef] 
39. Hernández-Hernández, H.; Juárez-Maldonado, A.; Benavides-Mendoza, A.; Ortega-Ortiz, H.; Cadenas-Pliego, G.; Sánchez-Aspeytia, D.; González-Morales, S. Chitosan-PVA and copper nanoparticles improve growth and overexpress the SOD and JA genes in tomato plants under salt stress. Agronomy 2018, 8 , 175. [CrossRef]

40. Silveira, N.M.; Seabra, A.B.; Marcos, F.C.C.; Pelegrino, M.T.; Machado, E.C.; Ribeiro, R.V. Encapsulation of S-nitrosoglutathione into chitosan nanoparticles improves drought tolerance of sugarcane plants. Nitric Oxide 2019, 84, 38-44. [CrossRef]

41. Lustriane, C.; Dwivany, F.N.; Suendo, V.; Reza, M. Effect of chitosan and chitosan-nanoparticles on post harvest quality of banana fruits. J. Plant Biotechnol. 2018, 45, 36-44. [CrossRef]

42. Mannozzi, C.; Tylewicz, U.; Chinnici, F.; Siroli, L.; Rocculi, P.; Dalla Rosa, M.; Romani, S. Effects of chitosan based coatings enriched with procyanidin by-product on quality of fresh blueberries during storage. Food Chem. 2018, 51, 18-24. [CrossRef]

43. Chen, C.; Nie, Z.; Wan, C.; Chen, J. Preservation of Xinyu tangerines with an edible coating using Ficus hirta Vahl. fruits extract-incorporated chitosan. Biomolecules 2019, 9, 46. [CrossRef] [PubMed]

44. Luksiene, Z.; Buchovec, I. Impact of chlorophyllin-chitosan coating and visible light on the microbial contamination, shelf life, nutritional and visual quality of strawberries. Innov. Food Sci. Emerg. Tecnol. 2019, 52, 463-472. [CrossRef]

45. Kou, X.; He, Y.; Li, Y.; Chen, X.; Feng, Y.; Xue, Z. Effect of abscisic acid (ABA) and chitosan/nano-silica/sodium alginate composite film on the color development and quality of postharvest Chinese winter jujube (Zizyphus jujuba Mill. cv. Dongzao). Food Chem. 2019, 270, 385-394. [CrossRef] [PubMed]

46. Tian, F.; Chen, W.; Wu, C.; Kou, X.; Fan, G.; Li, T.; Wu, Z. Preservation of Ginkgo biloba seeds by coating with chitosan/nano-TiO ${ }_{2}$ and chitosan/nano-SiO 2 films. Int. J. Biol. Macromol. 2019, 126, 917-925. [CrossRef]

47. Iriti, M.; Faoro, F. Chitosan as a MAMP, searching for a PRR. Plant Signal Behav. 2009, 4, 66-68. [CrossRef] [PubMed]

48. Malerba, M.; Cerana, R. Reactive oxygen and nitrogen species in defense/stress responses activated by chitosan in sycamore cultured cells. Int. J. Mol. Sci. 2015, 16, 3019-3034. [CrossRef]

49. Petutschnig, E.K.; Jones, A.M.E.; Serazetdinova, L.; Lipka, U.; Lipka, V. The lysin motif receptor-like kinase (LysM-RLK) CERK1 is a major chitin-binding protein in Arabidopsis thaliana and subject to chitin-induced phosphorylation. J. Biol. Chem. 2010, 285, 28902-28911. [CrossRef]

50. Gubaeva, E.; Gubaev, A.; Melcher, R.L.J.; Cord-Landwehr, S.; Singh, R.; El Gueddari, N.E.; Moerschbacher, B.M. 'Slipped sandwich' model for chitin and chitosan perception in Arabidopsis. Mol. Plant Microbe Interact. 2018, 31, 1145-1153. [CrossRef]

51. Kwak, S.-Y.; Lew, T.T.S.; Sweeney, C.J.; Koman, V.B.; Wong, M.H.; Bohmert-Tatarev, K.; Snell, K.D.; Seo, J.S.; Chua, N.-H.; Strano, M.S. Chloroplast-selective gene delivery and expression in planta using chitosan-complexed single-walled carbon nanotube carriers. Nat. Nanotechnol. 2019, 14, 447-455. [CrossRef] 